\title{
Challenges of Athletes after Career Termination in the Light of Relational Family Therapy
}

\section{Introduction}

Changes in life can be a major challenge. This applies in the area of sports as well. On one hand, sports can be defined as a universal human experience; on the other hand, it is something very personal and unique to the athlete. Intensive involvement with sports brings a certain risk of addiction to physical exercise and thus, withdrawal symptoms after the end of one's sports career. This is one of the reasons why we can assume that retirement from sport is a sensitive period in the athlete's life, requiring a certain adjustment process. Sport retirement is also referred to as the first "death" in the lives of athletes. This article is an attempt at an innovative and integrative reflection on the termination of a sports career. Our main purpose is to shed light on athletes' experiencing the end of their sports careers and the challenges they face during that time from a therapeutic and theological perspective. We shall therefore present the use of the Relational Family Therapy model as a possibility to help athletes cope with the end of their careers. Finally, 
we will link this topic with a spiritual component, which is an integral part of any therapeutic process based on dialogue and a holistic approach to an individual. The issue of sport retirement is quite specific and rather topical, and it offers new possibilities for the use of complementary approaches in its research.

\section{Sport career termination and its consequences}

\subsection{Sport career termination}

Sport career termination is considered a delicate transition in an athlete's life, requiring a certain adjustment process. ${ }^{1}$ Regardless of the different responses of athletes and the results of research in the field of sport careers, the results show that sport career termination can lead to various adaptation problems and distress in many athletes. ${ }^{2}$ Recent data and estimates suggest that about one-fifth of the top athletes experience severe distress and adaptation issues after retirement from sport, and therefore need psychological help. Most studies even report that some athletes experience certain transitional problems and related negative emotions. ${ }^{3}$

The reasons for sport career termination may vary. The circumstances and the issue of decision-making for sport career termination are of great importance. ${ }^{4}$ The decision to terminate a sport career may be voluntary or

$1 \quad$ J. J. Coakley, Leaving Competitive Sport: Retirement or Rebirth?, “Quest” 35 (1983)

1, pp. 1-11. N. K. Schlossberg, A Model for Analyzing Human Adaptation to Transition, "The Counseling Psychologist” 9 (1981) 2, pp. 2-18.

2 E. M. Blinde, T. M. Stratta, The "Sport Career Death" of college athletes: Involuntary and unanticipated sport exits, "Journal of Sport Behavior" 15 (1992) 1, pp. 3-20. N. Stambulova, D. Alfermann, T. Statler, J. Cote, ISSP Position Stand: Career Development and Transitions of Athletes, "International Journal of Sport and Exercise Psychology" 7 (2009) 4, pp. 395-412. P. Werthner, T. Orlick, Retirement experiences of successful Olympic athletes, "International Journal of Sport Psychology" 17(1986) 5, pp. 337-363.

3 S. Park, D. Lavallee, D. Tod, Athletes' career transition out of sport: a systematic review, "International Review of Sport and Exercise Psychology" 6 (2013) 1, pp. 22-53. N. Stambulova, D. Alfermann, T. Statler, J. Cote, ISSP Position Stand: Career Development and Transitions of Athletes, "International Journal of Sport and Exercise Psychology" 7 (2009) 4, pp. 395-412.

4 A. Kuettel, E. Boyle, J. Schmid, Factors contributing to the quality of the transition out of elite sports in Swiss, Danish, and Polish athletes, "Psychology of Sport and Exercise" 
involuntary; other reasons may be injuries and deselection. ${ }^{5}$ Quantitative research, in particular, shows ${ }^{6}$ that the subjective feeling of decision making, be it either voluntary or involuntary, and timely planning play a crucial role in the (dis)ability of adaptation to retirement; however, this is not always the case. ${ }^{7}$ Individual examples of qualitative research ${ }^{8}$ note only a vague distinction between involuntary and voluntary retirement, since athletes who have retired voluntarily are not necessarily free from adjustment difficulties; and on the other hand, retired athletes with strong sporting identities, generally associated with major transitional adjustment problems, do not always experience difficulties in retirement. ${ }^{9}$ Research shows that the individuals who reacted more negatively (with negative emotions) to retirement, also expressed their negative emotions to a lesser degree. $^{10}$

29 (2017), pp. 27-39. W. M. Webb, S. A. Nasco, S. Riley, B. Headrick, Athlete Identity and Reactions to Retirement from Sports, "Journal of Sport Behavior" 21 (1998) 3, pp. 338-362.

5 W. M. Webb, S. A. Nasco, S. Riley, B. Headrick, Athlete Identity and Reactions to Retirement from Sports, "Journal of Sport Behavior" 21 (1998) 3, pp. 338-362.

$6 \quad$ S. CecićErpič, Saša, P. Wylleman, M. Zupancic, The effect of athletic and non-athletic factors on the sports career termination process, "Psychology of Sport and Exercise" 5 (2004) 1, pp. 45-59. R. M. Hatamleh, The life transitions of high performance athletes retirement from sport, "European Scientific Journal" 9 (2013) 11, pp. 336-353. A. Kuettel, E. Boyle, J. Schmid, Factors contributing to the quality of the transition out of elite sports in Swiss, Danish, and Polish athletes, "Psychology of Sport and Exercise" 29 (2017), pp. 27-39. W. M. Webb, S. A. Nasco, S. Riley, B. Headrick, Athlete Identity and Reactions to Retirement from Sports, "Journal of Sport Behavior" 21 (1998) 3, pp. 338-362.

7 G. Kerr, A. Dacyshyn, The Retirement Experiences of Elite, Female Gymnasts, "Journal of Applied Sport Psychology" 12 (2000) 2, pp. 115-133. M. Torregrosa, M. Y. Ramis, S. Pallares, F. Azocar, C. Selva, Olympic athletes back to retirement: A qualitative longitudinal study, "Psychology of Sport and Exercise" 21 (2015), pp. 50-56.

$8 \quad$ G. Kerr, A. Dacyshyn, The Retirement Experiences of Elite, Female Gymnasts, "Journal of Applied Sport Psychology" 12 (2000) 2, pp. 115-133. M. F. Perna, A. L. Rebecca, L. Zaichkowsky, The Influence of Career Planning, Race, and Athletic Injury on Life Satisfaction Among Recently Retired Collegiate Male Athletes, "Sport Psychologist" 13 (199) 2, pp. 144-156.

9 C. D’Angelo, E. Reverberi, D. Gazzaroli, C. Gozzoli, At the end of the match: exploring retirement of Italian football players, "Journal of Sport Psychology" 26 (2017) 3, pp 130-134.

10 D. Alfermann, N. Stambulova, A. Zemaityte. 2004. Reactions to sport career termination: a cross-national comparison of German, Lithuanian, and Russian athletes, "Psychology of Sport and Exercise" 5 (2004) (1), pp. 61-75. 


\subsection{Reactions to sport career termination}

Research has shown that a difficult transition can manifest in various issues, e.g. as anxiety, depression, isolation and substance abuse, ${ }^{11}$ emotional problems, ${ }^{12}$ lower self-esteem, ${ }^{13}$ lower self-control, ${ }^{14}$ disorientation, the feeling of emptiness, and frustration. ${ }^{15}$ Furthermore, the effects of sport retirement are associated with the effects of personal losses and the feelings of losing one's control and identity. ${ }^{16}$ Littll $^{17}$ developed the notion of "sports neurosis", which indicates serious problems associated with the sudden termination of a sport career and manifests as a painful response to the loss of a part of oneself. Sport is, by its very nature, an exclusive and intense activity, characterized by certain levels of addiction, and therefore by higher vulnerability and risk in case of its deprivation, particularly if it is unexpected. Data show that athletes who have experienced retirement as a one-way street (as in "tunnel vision", with no career alternatives, etc.) felt less social support (relations) and mentioned some other problems, such as

11 E. M. Blinde, T. M. Stratta, The "Sport Career Death" of college athletes: Involuntary and unanticipated sport exits, "Journal of Sport Behavior" 15 (1992) 1, pp. 3-20. B. W. Brewer, Self-identity and specific vulnerability to depressed mood, "Journal of Personality" 61 (1993) 3, pp. 343-364. B. C. Ogilvie, M. Howe, Career crisis in sport, In: T. Orlick, J.T. Partington, J. H. Salmela (Eds.), "Proceedings of the Fifth World Congress of Sport Psychology", pp. 176183, Ottawa, Canada, 1982, Coaching Association of Canada. G. Sanders, C. Stevinson, Associations between retirement reasons, chronic pain, athletic identity, and depressive symptoms among former professional footballers, "European Journal of Sport Science" 17 (2017) 10, pp. 1311-1318. M. Torregrosa, M. Y. Ramis, S. Pallares, F. Azocar, C. Selva, Olympic athletes back to retirement: A qualitative longitudinal study, "Psychology of Sport and Exercise" 21 (2015), pp. 50-56.

12 D. Alfermann, N. Stambulova, A. Zemaityte. 2004. Reactions to sport career termination: a cross-national comparison of German, Lithuanian, and Russian athletes, "Psychology of Sport and Exercise" 5 (2004) (1), pp. 61-75.

13 A. D. Sinclair, T.Orlick,Positive Transitions from High-Performance Sport, “The Sport Psychologist" 7 (1993) 2, pp.138-150.

14 P. Werthner, T. Orlick, Retirement experiences of successful Olympic athletes, "International Journal of Sport Psychology" 17(1986) 5, pp. 337-363.

15 G. Kerr, A. Dacyshyn, The Retirement Experiences of Elite, Female Gymnasts, "Journal of Applied Sport Psychology" 12 (2000) 2, pp. 115-133.

16 B. W. Brewer, Self-identity and specific vulnerability to depressed mood, "Journal of Personality" 61 (1993) 3, pp. 343-364. G. Kerr, A. Dacyshyn, The Retirement Experiences of Elite, Female Gymnasts, "Journal of Applied Sport Psychology" 12 (2000) 2, pp. 115-133. D. Lavallee, H. K. Robinson, In pursuit of an identity: A qualitative exploration of retirement from women's artistic gymnastics, "Psychology of Sport and Exercise" 8 (2007) 1, pp. 119-141.

17 R. E. Pearsons, A. J. Petitpas,Transitions of Athletes: Developmental and Preventive Perspectives, "Journal of Counseling \& Development" 69 (1990) 1, pp. 7-10. 
alcohol and drug abuse. ${ }^{18}$ Numerous studies and literature show that during their competitive careers with intense training and competitions, as well as in the adaptive or transitional period after the end of career, athletes are subject to stress, although this should not be generalized. ${ }^{19}$

Based on research, it can be assumed that intense sports involve a certain risk of exercise addiction as well as other sports-related addictions (e.g. competition, pressure, media recognition, fame) and, consequently, the symptoms of withdrawal during deprivation after sport career termination. Generally, the concept of addiction is often referred to as chemical addiction to drugs or alcohol, but behaviors such as, for example, gambling, sexuality, shopping, internet games as well as physical exercise, can be addictive, too. ${ }^{20}$ Such addictive behaviors show symptoms similar to drug addiction. ${ }^{21}$ The results of the latest studies show that athletes who are addicted to exercise and cease their regular training process develop withdrawal symptoms, manifested as heightened anxiety, depressive symptoms and psychoemotional states modulation. Furthermore, mental changes are reflected in altered physiological functioning - e.g. lower bioelectric activity in the brain, increased muscular tension, enhanced functioning of the sympathetic nervous system, etc. The athlete's functional state during the interruption (deprivation) of exercise, which reflects the termination of sport career in its own way, is thus an important element in predicting exercise addiction. ${ }^{22}$

18 M. Torregrosa, Miquel, Y. Ramis, S. Pallares, F. Azocar, C. Selva. 2015. Olympic athletes back to retirement: A qualitative longitudinal study, "Psychology of Sport and Exercise" 21 (2015), pp. 50-56.

19 B. W. Brewer, T. A. Petrie, Psychopathology in Sport and Exercise, In: J. L. Van Raalte, B. W. Brewer (Eds.), "Exploring Sport and Exercise Psychology", 311-335. Washington. DC (2014), US: American Psychological Association. R. M. Hatamleh, The life transitions of high performance athletes' retirement from sport, "European Scientific Journal" 9 (2013) 11, pp. 336-353; G. Sanders, C. Stevinson, Associations between retirement reasons, chronic pain, athletic identity, and depressive symptoms among former professional footballers, "European Journal of Sport Science" 17 (2017) 10, pp. 1311-1318. B. N. Stambulova, Crisis-transitions in athletes: current emphases on cognitive and contextual factors, "Current Opinion in Psychology” 16 (2017), pp. 62-66. N. Stambulova, D. Alfermann, T. Statler, J. Cote, ISSP Position Stand: Career Development and Transitions of Athletes, "International Journal of Sport and Exercise Psychology" 7 (2009) 4, pp. 395-412.

20 M. Griffiths, Behavioural addiction: an issue for everybody, "Employee Counselling Today: The Journal of Workplace Learning" 8 (1996) 3), pp. 19-25.

21 J. Adams, R. J. Kirkby, Excessive exercise as an addiction: A review "Addiction Research and Theory" 10 (2002) 5, pp. 415-437.

22 S. Krivoschekov,O. N. Lushnikov, The Functional State of Athletes Addicted to Exercises during Exercise Deprivation, "Human Psychology" 43 (2017) 6, pp. 678-685. J. Adams, 
Some literature and studies show that the stronger the commitment to training that can lead to addiction, the higher the risk of withdrawal symptoms and deprivation sensations in the period of abstaining from exercise; these symptoms are both physiological and psychological. ${ }^{23}$ Here it is necessary to add that in the definition of addiction, two elements are essential, namely addiction and compulsivity, whereby such behavior can provide satisfaction or alleviate internal discomfort, e.g. stress or anxiety. ${ }^{24}$

\section{The process of transition and interventions with athletes}

\subsection{Career termination as a transition}

The concept of transition is a broad one, also including the retirement process. In sport psychology, this concept has emerged as a question of how former athletes deal with retirement from professional sport, i.e. sport at a high competitive level. Initially, sports retirement was regarded as a oneoff event, with certain (especially negative) consequences, but scientists and researchers eventually began to regard career termination as a transitional process, ${ }^{25}$ since career termination was no longer associated with the so called "social death": rather, career termination began to be considered a possibility of "social rebirth". ${ }^{26}$ Sport career termination is no longer exclusively in the domain of sports: it was a sports transition associated

R. J. Kirkby, Excessive exercise as an addiction: A review "Addiction Research and Theory" 10 (2002) 5, pp. 415-437.

23 J. Adams, R. J. Kirkby, Excessive exercise as an addiction: A review "Addiction Research and Theory" 10 (2002) 5, pp. 415-437. K. Berczik, A. Szabo, M. D. Griffiths, T. Kurimay, B. Kun, R. Urban, Z. Demetrovics, Exercise Addiction: Symptoms, Diagnosis, Epidemiology, and Etiology, "Substance Use \& Misuse" 47 (2012), pp. 403-417. S. Krivoschekov, O. N. Lushnikov, The Functional State of Athletes Addicted to Exercises during Exercise Deprivation, "Human Psychology" 43 (2017) 6, pp. 678-685. E. Landolf, Exercise Addiction, "Sports Medicine" 43 (2013), pp. 111-119.

24 K. Berczik, A. Szabo, M. D. Griffiths, T. Kurimay, B. Kun, R. Urban, Z. Demetrovics, Exercise Addiction: Symptoms, Diagnosis, Epidemiology, and Etiology, "Substance Use \& Misuse" 47 (2012), pp. 403-417. A. Goodman, Addiction: definition and implications, "British Journal of Addiction" 85 (1990), pp. 1403-1408.

25 P. Wylleman, D. Alferman, D. Lavallee, Career transitions in sport: European perspectives, "Psychology of Sport and Exercise" 5 (2004) 1, pp. 7-20.

26 J. J. Coakley, Leaving Competitive Sport: Retirement or Rebirth? “Quest” 35 (1983) 1, pp. $1-11$. 
with (un)responsiveness, which manifests in one's abilities to change their perception of the world, relationships and oneself. Various factors should be taken into account in the process of transition, in particular the characteristics of the individual experiencing transition (e.g. psychosocial competence, gender, age, past experience, socioeconomic status, etc.), one's perception of one's own transition (e.g. the change of roles, affects, stress, onset / timing, etc.) and the characteristics of the pre- and post-transitional environment (e.g. family support, institutional support, etc.). ${ }^{27}$ However, it should be emphasized that, despite the upgrading of older approaches, the first transitional models focused primarily on the effects of the transition, which manifested as either positive or negative adjustment to retirement. At the end of the 1990s, more thorough and conceptual transitional models came to the fore, which also included: coping resources that affect the responses to career transition, the quality of adjustment to career transition and possible treatment issues for distressful reaction to career transition. Some analytical concepts have focused on the stages of the retirement process, namely: retirement as a true withdrawal from sport, a period of uncertainty (the so-called 'nowhere land') and a period of new beginnings. The next step in dealing with sports retirement has evolved from a specific transition (career termination) to the athlete's lifetime perspective as a more holistic approach. ${ }^{28}$ In short, there has been a shift in the research of sport career, from studying the termination of sport career as such to a more comprehensive, lifelong and multi-level approach to studying the sports career and the life after it. This was a shift from focusing on sport transitions exclusively in sports to a more personal, holistic perspective of an individual's life, which allows a look at sport transitions in relation to development challenges and transitions in other areas of the athlete's life. ${ }^{29}$

Sport career termination is an inevitable process that happens to every athlete, but this process is affected by various factors and causes. In general,

\footnotetext{
27 N. K. Schlossberg, A Model for Analyzing Human Adaptation to Transition, "The Counseling Psychologist" 9 (1981) 2, pp. 2-18.

28 P. Wylleman, D. Alferman, D. Lavallee, Career transitions in sport: European perspectives, "Psychology of Sport and Exercise" 5 (2004) 1, pp. 7-20. G. Kerr, A. Dacyshyn, The Retirement Experiences of Elite, Female Gymnasts, "Journal of Applied Sport Psychology" 12 (2000) 2, pp. 115-133.

29 N. Stambulova, D. Alfermann, T. Statler, J. Cote, ISSP Position Stand: Career Development and Transitions of Athletes, "International Journal of Sport and Exercise Psychology" 7 (2009) 4, pp. 395-412.
} 
research findings about sport retirement and consequent transitions indicate that some factors (voluntary decision about retirement, planning of retirement and life after it, personal characteristics, social support) have a more positive impact on transition, while some other factors (strong athletic identity, involuntary retirement, health problems, negative life events) have a more negative impact. ${ }^{30}$ However, some studies examining the experience of athletes after retirement revealed a lack of clarity in the generalization of factors affecting the quality of retirement and transition. ${ }^{31}$ Although some former athletes can experience a wide range of hardships and problems, the origin of these problems may not be very much related to their sporting engagement in the past, ${ }^{32}$ since in addition to sports, retirement and transition factors, early life experiences ${ }^{33}$ and non-sporting factors ${ }^{34}$ play an important role. A certain limitation of the quantitative research of sports transition has emerged, namely that such research does not hear enough of the athletes' voice and does not sufficiently encompass the experiential nature of the transition process. ${ }^{35}$

30 D. Alfermann, N. Stambulova, Career transitions and career termination. In: G. Tenenbaum, R. C. Eklund (Eds.), „Handbook of sport psychology“, 712-736, New York, 2007, Wiley. S. Park, D. Lavallee, D. Tod, Athletes' career transition out of sport: a systematic review, "International Review of Sport and Exercise Psychology" 6 (2013) 1, pp. 22-53. N. Stambulova, D. Alfermann, T. Statler, J. Cote, ISSP Position Stand: Career Development and Transitions of Athletes, "International Journal of Sport and Exercise Psychology" 7 (2009) 4, pp. 395-412.

31 C. D’Angelo, E. Reverberi, D. Gazzaroli, C. Gozzoli, At the end of the match: exploring retirement of Italian football players, "Journal of Sport Psychology" 26 (2017) 3, pp. 130134. G. Kerr, A. Dacyshyn, The Retirement Experiences of Elite, Female Gymnasts, "Journal of Applied Sport Psychology” 12 (2000) 2, pp. 115-133. M. Torregrosa, M. Y. Ramis, S. Pallares, F. Azocar, C. Selva, Olympic athletes back to retirement: A qualitative longitudinal study, "Psychology of Sport and Exercise” 21 (2015), pp. 50-56.

32 J. J. Coakley, Leaving Competitive Sport: Retirement or Rebirth?, “Quest” 35 (1983) 1, pp. $1-11$.

33 J. Taylor, B. C. Ogilvie, Career transition among elite athletes: is there life after sports?, in: J. M. Williams (Ed.), "Applied sport psychology: Personal growth to peak performance”, 429-444, CA: Mayfield, 1998, Mountain View.

34 S. Cecić Erpič, P. Wylleman, M. Zupancic, The effect of athletic and non-athletic factors on the sports career termination process, "Psychology of Sport and Exercise" 5 (2004) 1, pp. 45-59. N. Stambulova, D. Alfermann, T. Statler, J. Cote, ISSP Position Stand: Career Development and Transitions of Athletes, "International Journal of Sport and Exercise Psychology" 7 (2009) 4, pp. 395-412. P. Wylleman, D. Alferman, D. Lavallee, Career transitions in sport: European perspectives, "Psychology of Sport and Exercise" 5 (2004) 1, pp. 7-20.

35 G. Kerr, A. Dacyshyn, The Retirement Experiences of Elite, Female Gymnasts, "Journal of Applied Sport Psychology” 12 (2000) 2, pp. 115-133. 


\subsection{Interventions with athletes in transition}

To deal with retirement and to learn about their emotional response to it, and above all, to transform their deeper behavioral patterns, inner attitude and relationships, athletes who have ended their sport career and are facing a multitude of consequences and issues may need expert help or support. Emotional processing is an essential element of mental health, ${ }^{36}$ which is thus established and maintained in intimate relationships permeated with the psycho-biological component. ${ }^{37}$ Effective regulation of emotional states is important for social adjustment and general well-being. ${ }^{38}$ Findings and research in different areas show that the suppression of emotional responses and unhealthy responses are often associated with various forms of mental disorders and psychopathology, ${ }^{39}$ social issues ${ }^{40}$ and physical illnesses. ${ }^{41}$

Through the growing awareness of the importance of various transitions in sport, which can also be accompanied by other life transitions, the need for interventions with athletes in transition has also increased. ${ }^{42}$ Some previous studies show that pursuing new interests, keeping busy and

36 A. N. Schore, Right Brain Affect Regulation: An Essential Mechanism of Development, Trauma, Dissociation, and Psychotherapy, In: D. Fosha, D. Siegel, M. F. Solomon. (Eds.), "The healing power of emotion: affective neuroscience, development, and clinical practice", 112144, New York, London, 2009, W. W. Norton.

37 C. Gostečnik, Inovativna relacijska družinska terapija [Innovative Relational Family Therapy], Ljubljana 2011, Brat Frančišek in Frančiškanski družinski inštitut.

38 L. Campbell-Sills, D. H. Barlow, T. A. Brown, S.G. Hofmann, Effects of suppression and acceptance on emotional responses of individuals with anxiety and mood disorders, "Behaviour Research and Therapy" 44 (2006) 9, pp. 1251-1263.

39 T. P. Beauchaine, A. Zisner, Motivation, emotion regulation, and the latent structure of psychopathology: An integrative and convergent historical perspective, "International Journal of Psychophysiology"119 (2017), pp. 108-118. S. G. Hofmann, A. T. Sawyer, A. Fang, A. Asnaani, Emotion Dysregulation Model of Mood and Anxiety Disorders, "Depression and Anxiety” 29 (2012) 5), pp. 409-416. L. Villalta, P. Smith, N. Hickin, A. Stringaris, Emotion regulation difficulties in traumatized youth: a metaanalysis and conceptual review, "European Child \& Adolescent Psychiatry” 27 (2018) 4, pp. 527-544.

40 T. Wranik, L. F. Barrett, P. Salovey, Intelligent emotional regulation: Is knowledge power? In: J. J. Gross (Ed.), "Handbook of emotion regulation”, pp. 393-408, New York, 2006, Guilford Press.

41 R. M. Sapolsky, Stress, Stress-Related Disease, and Emotional Regulation. In: James J. Gross (Ed.), "Handbook of emotion regulation”, pp. 606-615, New York, US, 2007, Guilford Press.

42 P. Wylleman, D. Alferman, D. Lavallee, Career transitions in sport: European perspectives, "Psychology of Sport and Exercise" 5 (2004) 1, pp. 7-20. 
exercising are the most efficient methods for coping with transition stress, while personal counseling is surprisingly seen as less effective; ${ }^{43}$ we should point out, however, that in the beginning, mostly traditional therapeutic approaches (e.g. stress management, cognitive restructuring, emotional expression) were applied as a response to retirement as a potentially traumatic experience. ${ }^{44}$ With increasing awareness of the importance of career transition, the need for appropriate interventions, which could adequately assist athletes in coping with transition, has increased. ${ }^{45}$ The importance of therapeutic interventions which focus on the emotional response to stressful life events, such as sports retirement, is noticeable. ${ }^{46}$ Despite preventive strategies, hardships and problems associated with sport career termination can occur with delay or only when the athlete actually becomes aware of it, and experiencing this can negatively impact athletes physically, behaviorally, cognitively, emotionally and socially. ${ }^{47}$ The expression of emotions and feelings to the experience of retirement within the micro-narrative approach has proved useful for the post-retirement adjustment process. ${ }^{48}$

It should also be noted that, according to our knowledge, various therapeutic interventions and support programs in sport psychology focus primarily on the post-retirement adjustment process or positive transition of

43 G. J. Lotysz, S. E. Short. 2004, "What Ever Happened To....”: The Effects of Career Termination from the National Football League, "The Online Journal of Sport Psychology" 6 (2004) 3, pp. 47-66. A. D. Sinclair, T. Orlick, Positive Transitions from High-Performance Sport, “The Sport Psychologist” 7 (1993) 2, pp. 138-150.

44 P. Wylleman, D. Alferman, D. Lavallee, Career transitions in sport: European perspectives, "Psychology of Sport and Exercise" 5 (2004) 1, pp. 7-20.

45 S. Gordon, D.Lavallee, Career transitions, in: T. Morrisand P. Terry (Eds.), "The new sport and exercise psychology companion”, pp. 567-582, Morgantown WV, 2012, Fitness Information Technology. P. Wylleman, D. Alferman, D. Lavallee, Career transitions in sport: European perspectives, "Psychology of Sport and Exercise" 5 (2004) 1, pp. 7-20.

46 D. Lavallee, S. Gordon, J. R. Grove, Retirement from sport and the loss of athletic identity, "Journal of Personal and Interpersonal Loss" 2 (1997) 2, pp. 129-147. K. McKnight, K. Bernes, T. Gunn, D. Chorney, D. Orr, David, A. Bardick, Life After Sport: Athletic Career Transition and Transferable Skills, "Journal of Excellence" 13 (2009), pp. 63-77.

47 J. Taylor, B. C. Ogilvie, Career transition among elite athletes: is there life after sports?, in: J. M. Williams (Ed.), "Applied sport psychology: Personal growth to peak performance”, 429-444, CA: Mayfield, 1998, Mountain View.

48 D. Lavallee, S. Gordon, J. R. Grove, Retirement from sport and the loss of athletic identity, "Journal of Personal and Interpersonal Loss" 2 (1997) 2, pp. 129-147. 
former athletes; ${ }^{49}$ these programs are supposed to help athletes particularly to adapt to retirement better and/or faster. One of various interventions is the model of marital therapy, which focuses on relational topics in sport, with an emphasis on the sport career. ${ }^{50}$ In interventions that are more narrowly oriented to the transition itself, when addressing adaptation problems there is perhaps less emphasis on the wider relational dynamics and deeper affective states, which may also reflect primary patterns and other traumatic life experiences, not solely sports retirement. Relational therapeutic models include the Relational Family Therapy model, which will be presented as an alternative form of assistance or support to athletes.

\section{The Relational Family Therapy model}

\subsection{Relational shift in psychoanalysis}

In this section, we want to briefly introduce the Relational Family Therapy model (RFT), in particular its basic mechanisms, which can be applied to address clients' problems and encourage affect regulation, regardless of the sphere which they come from. The second half of the 20th century witnessed a change in the paradigm in psychoanalysis and psychotherapy with the advent of the relational theory, ${ }^{51}$ encompassing the innovative model of Relational Family Therapy Model, the author of which is Christian Gostečnik. RFT is an integrative model combining relational theories, the

49 Comp. S. Gordon, D. Lavallee, Career transitions. In: T. Morris in P. Terry (Eds.), "The new sport and exercise psychology companion", pp. 567-582, Morgantown WV, 2012, Fitness Information Technology. S. M. Murphy, Ed., Sport Psychology Interventions, Champaign, IL, 1995, Human Kinetics. A. D. Sinclair, T. Orlick, Positive Transitions from High-Performance Sport, “The Sport Psychologist” 7 (1993) 2, pp. 138-150. N. Stambulova, D. Alfermann, T. Statler, J. Cote, ISSP Position Stand: Career Development and Transitions of Athletes, "International Journal of Sport and Exercise Psychology" 7 (2009) 4, pp. 395-412. J. Taylor, B. C. Ogilvie, Career transition among elite athletes: is there life after sports? In: J. M. Williams (Ed.), "Applied sport psychology: Personal growth to peak performance", 429-444, CA: Mayfield, 1998, Mountain View.P. Wylleman, D. Alferman, D. Lavallee, Career transitions in sport: European perspectives, "Psychology of Sport and Exercise" 5 (2004) 1, pp. 7-20.

50 D. B. Coppel, David B, Relationship Issues in Sport: A Marital Therapy Model, In: S. M. Murphy (Ed.), "Sport Psychology Interventions”, pp. 193-204, Champaign, IL, 1995, Human Kinetics.

51 S. A. Mitchell, Relation concepts in psychoanalysis, New York, 1988, Basic Books. 
systems theory, and the biological component. Relational theories (objectrelational theory, self-psychology, interpersonal psychoanalysis) invalidated and upgraded Freud's theories, which have excluded the relationship, i.e. the individual as a relational being, treating him as an independent unit. The systems theory never treats persons individually, but as parts of a system. The family is understood as a system governed by internal rules that create family dynamics, which strongly influences the individual and shapes his intrapsychical structure, with which he enters relationships and other social systems. RFT combines all these theories into a psycho-organic paradigm, which is used to understand an individual as an integral part of the family system and other systems. ${ }^{52}$

\subsection{Basic mechanisms of RFT}

The basic assumption of RFT is that the relationships which an individual establishes with their caregivers in the primary family, with all emotional, mental, physical and behavioral expressions, is imprinted in his psychoorganic structure; these relationships are later transmitted as a pattern into adult relationships in order to be resolved. Therefore, unresolved mental contents that have a neurobiological, i.e. organic basis in the body and from the point of view of our topic - do not necessarily reflect participation in sports, are reflected in various symptoms and dysfunctional behaviors. RFT is based on five fundamental premises: the concept of the basic affect and the associated affective psychic construct, and on the mechanisms of affect regulation, projective and introjective identification and compulsive repetition. RFT studies the systemic, interpersonal and intrapsychic level of the individual's experience, and through the mechanisms of projective and introjective identification penetrates unconscious memory. By making unconscious memory conscious it helps transform affective psychic constructs and compulsive behaviors and regulate individual's psycho-biological states and affects arising from these states. Basic affects are organically based emotions or feelings. There are six basic affects (disgust, shame, anger, fear, sadness, joy), which often point to unconscious psychosomatic contents and

52 C. Gostečnik, Inovativna relacijska družinska terapija [Innovative Relational Family Therapy], Ljubljana, 2011, Brat Frančišek in Frančiškanski družinski inštitut. C. Gostečnik, Relational Family Therapy. The Systemic, Interpersonal, and Intrapsychic Experience, New York and London, 2017, Routledge. 
psycho-biological states. The purpose of therapy that establishes relations is to awaken these affects and psycho-biological states and to enable their regulation, which leads to establishing new perceptions and, most importantly, a new psychological structure. Affective psychic constructs as "safeguards" of the intrapsychic structure are based on suppressed basic affects and have the role of defensive mechanisms (cognitive, behavioral, emotional, etc.) that defend the individual against confrontation with his basic affect. Repressions, denials, and dissociations are the driving forces of old dysfunctional relationships or dysfunctional states that are all the more likely to emerge in critical moments, as in the case of sport career termination. RFT assumes that the body always remembers (implicit memory), therefore one is inclined to compulsively repeat their old psychoorganic contents with the goal of resolving them. This mechanism of compulsive repetition of different patterns (interactions, communication, conflict situations, trauma, behavioral models, actions etc.) leads to genuine addiction, which is also present in the world of sports, i.e. among athletes. The regulation of difficult affects and painful experiences is a crucial and highly demanding task of developmental psychology. Functional affect regulation results in the calming or strengthening of these affects by enabling the individual to respond appropriately to the situation which can be very delicate in the context of sport career termination. Therapeutic dialogue is therefore focused on discovering the old contents to find affect regulation strategies as well as on creating new contents. ${ }^{53}$

As shown in several sport psychology studies, ${ }^{54}$ the problems which former athletes need to cope with can be very complex, demanding

53 C. Gostečnik, Govorica telesa v psihoanalizi[Bodylanguage in psychoanalysis], Ljubljana, 2008, Brat Frančišek in Frančiškanski družinski inštitut. C. Gostečnik, Inovativna relacijska družinska terapija[InnovativeRelationalFamilyTherapy], Ljubljana, 2011, Brat Frančišek in Frančiškanski družinski inštitut. C. Gostečnik, T. Repič Slavič, T. Pate, R. Cvetek,Repetition Compulsion Revisited in Relational Family Therapy: The Discovery of Old in Order to Develop Something New, "Journal of Religion and Health" 58 (2019) 2, pp. 612-627.

54 S. Cecić Erpič, Saša, P. Wylleman, M. Zupancic, The effect of athletic and non-athletic factors on the sports career termination process, "Psychology of Sport and Exercise" 5 (2004) 1, pp. 45-59. A. Kuettel, E. Boyle, J. Schmid, Factors contributing to the quality of the transition out of elite sports in Swiss, Danish, and Polish athletes, "Psychology of Sport and Exercise" 29 (2017), pp. 27-39. N. Stambulova, D. Alfermann, T. Statler, J. Cote, ISSP Position Stand: Career Development and Transitions of Athletes, "International Journal of Sport and Exercise Psychology” 7 (2009) 4, pp. 395-412. P. Wylleman, D. Alferman, D. Lavallee, Career transitions in sport: European perspectives, "Psychology of Sport and Exercise" 5 (2004) 1, pp. 7-20. 
the treatment of the individual as a whole, his behavioral patterns and psychological dynamics as well as factors which are not related to sport. The theme of sports retirement is specific in its nature and content, because it basically belongs to sport psychology, but on the other hand, the problems faced by athletes are strongly intertwined with the scope and basic mechanisms of RFT: these problems can, namely, also stem from of the primary family environment, or are a reflection of relations with significant others, but notably they indicate the biological component, which is present in sport: and indeed the RFT model gives a special place to the body and body processes. At the beginning of RFT treatment of athletes, it is essential to evaluate the body, the emptiness and vacuum that sport career termination can bring and can be reflected in a variety of forms and withdrawal symptoms. The relationship between the therapist and the client creates a psycho-organic space that is sacred because it promises something new. We shall present the sacred dimension of the human body and relationships from the perspective of theology.

\section{Theology as an integrative part of sport}

\subsection{The transformation of psychological dynamics}

To begin with, we can point out the famous discourse that theology without psychology is impractical and vice versa, that psychology without theology is useless. Humans are relational beings, and the relationship is connecting and creating something new, which is also one of the meanings of the Latin word "religio." In his basic psychological structure, man longs for salvation and for resolving painful complications in his psychological life. This process can be followed in every therapy, and especially in relational therapy, where this process is called the transformation of psychological dynamics, which is consequently reflected in the change of the individual's attitude to the sacred, as the individual's sense of the sacred is reflected in his intrapsychic psycho-organic world. There is also the other side, namely, how the transformation in relation to the sacred or how the new vision of the sacred significantly influences the transformation of one's intrapsychic psycho-organic structure. Every human being yearns for this transformation 
after repeating old traumas, complications and unresolved conflicts. This is not an unreasonable pre-determined repetition of old complications and conflicts - in our case, the distress the athletes experience and act out after the end of career; rather, this repetition contains a desire for transformation. In the compulsive repetition mechanism, the spiritual dimension is essential, enabling an irresistible yearning for salvation. ${ }^{55}$

Sport is a universal human experience, which has a special meaning in modern times, and therefore has a special meaning in God's communion. The Church has recently issued the document "Giving the best of oneself" ("Dare ilmeglio di se"). The Church understands the human person as a whole, composed of body, soul, and spirit, and therefore wants to preserve human dignity in the world of sport, the same as in every other area. Every life, in general, is marked by biblical words "I have fought the good fight, I have finished the race, I have kept the faith", ${ }^{56}$ which is a particular aspect of sports, where every athlete wants to achieve his goals. It would be a mistake to think that the Church has a negative attitude towards the body. On the contrary, the material world created by God is good, as we can read: "God saw all that he had made, and it was very good." ${ }^{57}$ Sport supports an individual in finding the ultimate purpose, as it highlights the tension between power and weakness, which are so essentially associated with human existence. Athletes can live their gifts and creativity, but at the same time they are faced by their limitations and restrictions, as success is not guaranteed in any way, and sooner or later, the sport chapter in one's life ends, which is perhaps a greater challenge for athletes than all obstacles and perplexities they had dealt with during their career. Here we should mention that the Church document highlights four challenges in sports in the light of the gospel: the devaluation of the body, doping, corruption and fans/the audience. In our opinion, these challenges can manifest, in various ways even later, after the termination of one's sport career. ${ }^{58}$ At or after the

55 C. Gostečnik, Neustavljivo hrepenenje[Irresistible yearning], Ljubljana, 2006, Brat Frančišek in Frančiškanski družinski inštitut. C. Gostečnik, Relational Family Therapy. The Systemic, Interpersonal, and Intrapsychic Experience, New York and London, 2017, Routledge. C. Gostečnik, Psihoanaliza in sakralno izkustvo[Psychoanalysis and sacred experience], Ljubljana, 2018, Brat Frančišek in Frančiškanski družinski inštitut.

562 Tim. $4,7$.

57 Gen. 1,31.

58 Dikasterij za laike, družino in življenje, Dati vse od sebe (Dareilmeglio di se), Ljubljana (2019), Družina. 
end of his professional career, the athlete needs to face himself in a new way and ask himself who he is and where he is going.

\subsection{Yearning in biblical context}

We people can find the deepest truth about who we are in our image and similarity to God, because we were created in his image. ${ }^{59}$ Our life periods are characterized by changes and progressive development. The development of human consciousness takes place in time with its complexity. Human consciousness, based on the ability of reflection, ${ }^{60}$ works in time and represents the flow of thoughts, feelings, sensations and desires that constantly flow and change. And whatever is changing is incomplete. ${ }^{61}$

The spiritual dimension of the transformation described above is, in the deepest sense, presented in the Bible in a wide variety of cases and from various perspectives. Since, in this article, we focus on the transitional phenomenon of sport career termination, we shall consider transformation from the point of view of a specific interpretation of time. In the New Testament, the interpretation of time is presented through the distinction between the two Greek terms for time: "chronos" and "kairos". Chronos is also known as the "devouring" time, which depicts chronic behavior and marks the time of illness and preparation, and describes human life as wounded and unredeemed. Chronos can mean an event or experience with religious content and meaning, ${ }^{62}$ the time of waiting for something great and significant, ${ }^{63}$ the time of patience and persistence, ${ }^{64}$ and a new opportunity for transformation. ${ }^{65}$ Simultaneously, it can mean the time when one feels unsaved, the time of long, tedious and painful suffering, ${ }^{66}$ caused by the obsession by Satan. ${ }^{67}$ Chronos is also the time of the definitive goal or a

59 Gen. $1,27$.

60 C. Clulow, Partnership and marriage, In: E. Rayner, A. Joyce, J. Rose, M. Twyman in C. Clulow (Eds.), "Human development: An introduction to the psychodynamics of growth, maturity and ageing", 213-230, London, 2005, Routledge.

61 C. Gostečnik, Inovativna relacijska družinska terapija [Innovative Relational Family Therapy], Ljubljana, 2011, Brat Frančišek in Frančiškanski družinski inštitut.

62 Cf. Matt. 2,7; Luke 1,57.

63 Cf. Matt. 25,19; Mark 2,19; Luke 23,8.

64 Cf. Luke 18,4.

65 Cf. Rev. 2,21.

66 Cf. John 5,6.

67 Cf. Mark 9,21; Luke 8,27; 8,29. 
promise which shall be fulfilled, ${ }^{68}$ of the time of preparation for repentance and transformation. ${ }^{69}$ Kairos, on the contrary, is the time of "opportunity" that specifies the exact time of salvation, the opportunity for salvation and the decisive moment in the history of mankind. Simultaneously, this is the time of vulnerability, with a special meaning, an initiative and fulfillment. Kairos can mean the time of fulfillment of God's promises of salvation in the present, ${ }^{70}$ the exact determined time of God's revelation and salvation, ${ }^{71}$ and the decisive moment in the history of salvation. ${ }^{72}$ Kairos is a very special time of penance and conversion in order for us to engage in the grace of salvation, ${ }^{73}$ the time of prayer, ${ }^{74}$ a favorable time, the time of special grace, ${ }^{75}$ and an opportunity for salvation. ${ }^{76}$

To summarize in the context of our topic, the biblical expressions "chronos" and "kairos" have, in the light of compulsive repetition, two meanings. Chronos is the time when God promises salvation after longlasting pain, suffering, and crises that arise after sport career termination. Kairos, on the other hand, is the time of opportunity for spiritual, and thus also, psychological transformation and the fulfillment of unquenchable human yearning that does not cease with sport career termination. The time of chronos is the time of old projections stemming from the family of origin, the time of internal (sport) images which are constantly replayed, thus enabling the repetition of old behavioral models. At the time of kairos, however, these can gain a new meaning and the possibility of resolution and salvation, which is contained in our irresistible yearning. ${ }^{77}$

\footnotetext{
68 Cf. Acts 1,$21 ; 3,21 ; 7,17 ;$ John 7,33; 14,9.

69 Cf. Rev. 2,21.

70 Cf. Matt. 8,29; Rom. 3,26; Titus 9,9.

71 Cf. Luke 1,20; 8,13; Rom. 5,6; Titus 1,13.

72 Cf. Gal. 4,10; 2 Thess. 2,6.

73 Cf. Mark 1,15.

74 Cf. Luke 21,34; Rom. 12,11; 1 Cor. 7,5; Eph. 6,18.

75 Cf. 2 Cor. 6,2.

76 Cf. Luke 19,44.

77 C. Gostečnik, Neustavljivo hrepenenje[Irresistible yearning], Ljubljana, 2006, Brat
} Frančišek in Frančiškanski družinski inštitut. C. Gostečnik, Psihoanaliza in sakralno izkustvo[Psychoanalysis and sacred experience], Ljubljana, 2018, Brat Frančišek in Frančiškanski družinski inštitut. 


\section{Conclusions and future challenges}

In this paper, we presented the theme of sport career termination and the main challenges faced by former athletes. Research suggests that sport career termination can lead to various adaptation problems and hardships in athletes which can turn into genuine withdrawal crises. Sports retirement is considered a rapidly developing and sensitive issue. With the growing awareness of the importance of career transition, the need for appropriate interventions has also increased, which would adequately help athletes to cope with the transition to post-career life. That is why we focused on retirement from the point of view of the specific therapeutic model of RFT, and additionally from the theological perspective, which we have not yet seen in professional literature, at least in Slovenia. RFT has integrated relational and system theories into a psycho-organic paradigm which is used to understand an individual who is also an integral part of his family system and other social systems. The problems faced by former athletes can be very complex and require the treatment of the whole person and their experiences. Man is a relational being, and the relationship means connecting and creating something new, which is a fundamental aspect of every therapeutic process, especially a relational one. In his basic psychological structure, man longs for salvation and for resolving painful complications in his inner life, especially during times of great changes, such as sport career termination.

Based on numerous studies and the findings of this paper, we can propose RFT as a psycho-organic intervention in order to help athletes cope with the retirement process and take responsibility for their feelings. RFT can be used as an individual or group support for athletes and even as a partner support. The RFT model has been empirically tested on several occasions and has proven to be an effective approach in various fields, which can also be linked to sport related issues, such as emotional processing and affect regulation, personal losses, the abuse of alcohol and psychoactive substances, sexual and other abuses, physical punishment and stress management. The use of the RFT model has not yet been verified in such a specific population as athletes who have terminated their sports career. It would therefore be recommendable to create a pilot group, or to conduct a pilot study, that would help us better understand the lives of athletes, and especially their 
experiences after the sport career termination. In this way, athletes would be able to make a deeper evaluation of their past career and the transition to a new life. The results of numerous quantitative and qualitative studies in the field of the sport career are, to a certain extent, diverging and constantly opening up new questions. Therefore, we need to further explore the topic in the context of specific interventions, interdisciplinary approaches and a holistic view of the human being, which RFT undoubtedly offers.

\section{Bibliography}

Adams J., Kirkby R. J., Excessive exercise as an addiction: A review, "Addiction Research and Theory" 10 (2002) 5, pp. 415-437.

Alfermann D., Stambulova N., Zemaityte A., Reactions to sport career termination: a cross-national comparison of German, Lithuanian, and Russian athletes, "Psychology of Sport and Exercise" 5 (2004) 1, pp. 61-75.

Alfermann D., Stambulova N., Career transitions and career termination, in: Tenenbaum G., Eklund R. C. (Eds.), Handbook of sport psychology, pp. 712-736, New York, NY, 2007, Wiley.

BeauchaineT. P., Zisner A., Motivation, emotion regulation, and thelatent structure of psychopathology: An integrative and convergent historical perspective, "International Journal of Psychophysiology" 119 (2017), pp. 108-118.

Berczik K., Szabo A., Griffiths M. D., Kurimay T., Kun B., Urban R., Demetrovics Z., Exercise Addiction: Symptoms, Diagnosis, Epidemiology, and Etiology, "Substance Use \& Misuse" 47 (2012), pp. 403-417.

Blinde M. E., Stratta T. M., The "Sport Career Death" of college athletes: Involuntary and unanticipated sport exits, "Journal of Sport Behavior" 15 (1992) 1, pp. 3-20.

Brewer B. W., Self-identity and specific vulnerability to depressed mood, "Journal of Personality" 61 (1993) 3, pp. 343-364.

Brewer B. W., Cornelius A. E., Norms and Factorial Invariance of the Athletic Identity Measurement Scale (AIMS), "The Academic Athletic Journal" 15 (2001), pp. 103-113.

Brewer B. W., Petrie T. A., Psychopathology in Sport and Exercise, in: Van Raalte J. L., Brewer B. W. (Eds.), Exploring Sport and Exercise Psychology, 
pp. 311-335, Washington DC, 2014, American Psychological Association.

Campbell-Sills L., Barlow D. H., Brown T. A., Hofmann S. G., Effects of suppression and acceptance on emotional responses of individuals with anxiety and mood disorders, "Behaviour Research and Therapy" 44 (2006) 9, pp. 1251-1263.

Cecić Erpič S., Wylleman P., Zupancic M., The effect of athletic and nonathletic factors on the sports career termination process, "Psychology of Sport and Exercise" 5 (2004) 1, pp. 45-59.

Clulow C., Partnership and marriage, in: Rayner E., Joyce A., Rose J., Twyman M., ClulowC. (Eds.), Human development: An introduction to the psychodynamics of growth, maturity and ageing, pp. 213-230, London, 2005, Routledge.

Coakley J. J., Leaving Competitive Sport: Retirement or Rebirth?, “Quest 35 (1983) 1, pp. 1-11.

Coppel D. B., Relationship Issues in Sport: A Marital Therapy Model, in: Murphy S. M. (Ed.), Sport Psychology Interventions, pp. 193-204, Champaign, IL, 1995, Human Kinetics.

D’Angelo C., Reverberi E., Gazzaroli D., Gozzoli C., At the end of the match: exploring retirement of Italian football players, "Journal of Sport Psychology" 26 (2017) 3, pp. 130-134.

Dikasterij za laike, družino in življenje, Dati vseodsebe (Dareil meglio di se), Ljubljana 2019, Družina.

Goodman A., Addiction: definition and implications, "British Journal of Addiction" 85 (1992), pp. 1403-1408.

Gostečnik C., Neustavljivohrepenenje [Irresistible yearning], Ljubljana, 2006, Brat Frančišek in Frančiškanski družinski inštitut.

Gostečnik C., Govoricatelesa vpsihoanalizi [Bodylanguage in psychoanalysis], Ljubljana, 2008, Brat Frančišek in Frančiškanski družinski inštitut.

Gostečnik C., Inovativna relacijska družinska terapija [Innovative Relational Family Therapy], Ljubljana 2011, Brat Frančišek in Frančiškanski družinski inštitut.

Gostečnik C., Relational Family Therapy. The Systemic, Interpersonal, and Intrapsychic Experience, New York and London 2017, Routledge. 
Gostečnik C., Psihoanaliza in sakralnoizkustvo [Psychoanalysis and sacred experience], Ljubljana, 2018, Brat Frančišekin Frančiškanski družinski inštitut.

Gostečnik C., RepičSlavič T., Pate T., Cvetek R., Repetition Compulsion Revisited in Relational Family Therapy: The Discovery of Old in Order to Develop Something New, "Journal of Religion and Health" 58 (2019) 2, pp. 612-627.

Gordon S., Lavallee L., Career transitions. In: Morris T., Terry P. (Eds.), The new sport and exercise psychology companion, pp. 567-582. Morgantown WV, 2012, Fitness Information Technology.

Griffiths M., Behavioural addiction: an issue for everybody, "Employee Counselling Today: The Journal of Workplace Learning" 8 (1996) 3, pp. 19-25.

Hatamleh R. M., The life transitions of high performance athletes retirement from sport, "European Scientific Journal" 9 (2013) 11, pp. 336-353.

Hofmann S. G., Sawyer A. T., Fang A., Asnaani A., Emotion Dysregulation Model of Mood and Anxiety Disorders, "Depression and Anxiety" 29 (2012) 5, pp. 409-416.

Kerr G., Dacyshyn A., The Retirement Experiences of Elite, Female Gymnasts, "Journal of Applied Sport Psychology" 12 (2000) 2, pp. 115-133.

Krivoschekov S., Lushnikov O. N.,The Functional State of Athletes Addicted to Exercises during Exercise Deprivation, "Human Psychology" 43 (2017) 6, pp. 678-685.

Kuettel A., Boyle E., Schmid J., Factors contributing to the quality of the transition out of elite sports in Swiss, Danish, and Polish athletes, "Psychology of Sport and Exercise" 29 (2017), pp. 27-39.

Landolfi E., Exercise Addiction, "Sports Medicine" 43 (2013), pp. 111-119.

Lavallee D., Robinson H. K., In pursuit of an identity: A qualitative exploration of retirement from women's artistic gymnastics, "Psychology of Sport and Exercise" 8 (2007) 1, pp. 119-141.

Lavallee D., Gordon S., Grove J. R., Retirement from sport and the lossof athletic identity, "Journal of Personal and Interpersonal Loss" 2 (1997) 2, pp. 129-147.

Lotysz G. J., Short S. E., What Ever Happened To....”: The Effects of Career Termination from the National Football League, "The Online Journal of Sport Psychology" 6 (2004) 3, pp. 47-66. 
McKnight K., Bernes K., Gunn T., Chorney D., Orr D., Bardick A., Life After Sport: Athletic Career Transition and Transferable Skills, "Journal of Excellence" 13 (2009), pp. 63-77.

Mitchell S. A., Relation concepts in psychoanalysis, New York, 1988, Basic Books.

Murphy S. M. (Ed.), Sport Psychology Interventions, Champaign, IL, 1995, Human Kinetics.

Ogilvie b. C., Howe. M., Career crisis in sport, in: Orlick T., Partington J. T., Salmela J. H. (Eds.), Proceedings of the Fifth World Congress of Sport Psychology, pp. 176-183, Ottawa, Canada, 1982, Coaching Association of Canada.

Park S., Lavallee D., Tod D., Athletes' career transition out of sport: asystematic review, "International Review of Sport and Exercise Psychology" 6 (2013) 1, pp. 22-53.

Pearsons R. E., Petitpas A. J., Transitions of Athletes: Developmental and Preventive Perspectives, "Journal of Counseling \& Development" 69 (1990) 1, pp. 7-10.

Perna M. F., Rebecca A. L., Zaichkowsky L., The Influence of Career Planning, Race, and Athletic Injury on Life Satisfaction Among Recently Retired Collegiate Male Athletes, "Sport Psychologist" 13 (1999) 2, pp. 144-156.

Sanders G., Stevinson C., Associations between retirement reasons, chronic pain, athletic identity, and depressive symptoms among former professional footballers, "European Journal of Sport Science" 17 (2017) 10, pp. 1311 1318.

Sapolsky R. M., Stress, Stress-Related Disease, and Emotional Regulation, in: Gross J. J. (Ed.), Handbook of emotion regulation, pp. 606-615. New York, 2007, Guilford Press.

Schlossberg N. K.,A Model for Analyzing Human Adaptation to Transition, “The Counseling Psychologist” 9 (1981) 2, pp. 2-18.

Schore A. N., Right Brain Affect Regulation: An Essential Mechanism of Development, Trauma, Dissociation, and Psychotherapy, in: Fosha D., Siegel D., Solomon M. F. (Eds.), The healing power of emotion: affective neuroscience, development, and clinical practice, pp. 112-144, New York, London, 2009, W. W. Norton.

Sinclair A. D., Orlick T., Positive Transitions from High-Performance Sport, “The Sport Psychologist” 7 (1993) 2, pp. 138-150. 
Stambulova B. N., Crisis-transitions in athletes: current emphases on cognitive and contextual factors, "Current Opinion in Psychology" 16 (2017, pp. 62-66.

Stambulova N., Alfermann D., Statler T., Cote J.,ISSP Position Stand: Career Development and Transitions of Athletes, "International Journal of Sport and Exercise Psychology" 7 (2009) 4, pp. 395-412.

Taylor J., Ogilvie B. C., Career transition among elite athletes: is there life after sports?, in: Williams J. M. (Ed.), Applied sport psychology: Personal growth to peak performance, pp. 429-444, Mountain View CA, 1998, Mayfield.

Torregrosa M., Ramis Y., Pallares S., Azocar F., Selva C., Olympic athletes back to retirement: A qualitative longitudinal study, "Psychology of Sport and Exercise" 21 (2015), pp. 50-56.

Villalta L., Smith P., Hickin N., Stringaris A., Emotion regulation difficulties in traumatized youth: a meta-analysis and conceptual review, "European Child \&Adolescent Psychiatry" 27 (2018) 4, pp. 527-544.

Webb W. M., Nasco S. A., Riley S., Headrick B., Athlete Identity and Reactions to Retirement from Sports, "Journal of Sport Behavior" 21 (1998) 3, pp. 338-362.

Werthner P., Orlick T., Retirement experiences of successful Olympic athletes, "International Journal of Sport Psychology" 17 (1986) 5, pp. 337-363.

Wranik T., Barrett L. F., Salovey P., Intelligent emotional regulation: Is knowledge power?, in: Gross J. J. (Ed.), Handbook of emotion regulation, pp. 393-408, New York, 2006, Guilford Press.

Wylleman P., Alferman, D., Lavallee D., Career transitions in sport: European perspectives, "Psychology of Sport Exercise" 5 (2004) 1, pp. 7-20. 
